\begin{tabular}{|c|l|}
\hline Title & $\begin{array}{l}\text { Reinventing Ishinomaki, Reinventing Japan? Creative Networks, A Iternative Lifesty les and the Search for Qual ity of } \\
\text { Life in Post-growth Japan }\end{array}$ \\
\hline Author(s) & Klien, Susanne \\
\hline Citation & $\begin{array}{l}\text { Japanese Studies, 36(1),39-60 } \\
\text { https://doi.org/L0.1080/10371397.2016.1148555 }\end{array}$ \\
\hline Issue Date & 2016-05-17 \\
\hline Doc URL & http://hdl.handle.net/2115/77209 \\
\hline Rights & $\begin{array}{l}\text { This is an A ccepted Manuscript of an article published by Taylor \& Francis in Japanese Studies on 17/5/2016, available } \\
\text { online: http:/Www.tandfonline.com/10.1080/10371397.2016.1148555. }\end{array}$ \\
\hline Type & article (author version) \\
\hline File Information & \begin{tabular}{l} 
6article- klien_revised.pdf \\
\hline
\end{tabular} \\
\hline
\end{tabular}

Instructions for use 


\section{Reinventing Ishinomaki, reinventing Japan? Evolving creative networks, alternative lifestyles and the search for quality in life in post-growth Japan}

\section{Susanne Klien, Hokkaido University, Japan}

Abstract: This article aims to give an outline of recent developments in Ishinomaki, one of the worst affected cities struck by the Great East Japan Earthquake in March 2011. Before the disaster, the harbor town faced depopulation, aging residents, and a lack of prospects for the young, like many other stagnant regional cities. Since March 2011, Ishinomaki has seen an influx of short-, mid-, and long-term volunteers and young ambitious individuals who have moved from urban areas to initiate their own revitalization or social business projects. Drawing on and showing the limitations of Richard Florida's notion of the 'Creative Class', this paper approaches Ishinomaki's recent reinvention and transition from production to postindustrial multi-functionality as a phenomenon that can be seen as both a renaissance movement as well as the result of the structural instability of the labor market caused by Japan's transition into a mature postindustrial economy.

\section{Introduction}

"It's actually fun having two workplaces and places of residence. And in today's economically unstable world there is no absolute security. Having two places of residence and several jobs also means a reduction of risk. This lifestyle also helps to maintain my motivation and has a positive effect on me mentally speaking." 1

Amano Yuki, 35 years old, has maintained a nomad lifestyle commuting between Ishinomaki and Tokyo since May 2011. Educated as an architect she worked in architect offices for more than a decade before setting up her own design office and managing a communal living project in Tokyo. She has established a small restaurant called the "Hiyori Kitchen" in Ishinomaki that offers local cuisine prepared by Ishinomaki residents close to Ishinomaki station. At lunchtime classical set menus containing fresh

\footnotetext{
1 Cited in AnAn Magazine, 15 January 2014, 64.
} 
local fish are served while for dinner, guests can taste local venison. Amano observes that she does not see herself as someone living according to a long-term plan but rather adjusts her work flexibly to the respective needs of the situation. She says that in hindsight, her decision to spend considerable time in Ishinomaki was based on her gut instinct that she could make a valuable contribution there. ${ }^{2}$ The project combines regional revitalization, creation of workplaces, promotion of community human resources and attention to existing local industries. This is just one example of many projects that attempt to combine sustainability, post-disaster reconstruction, a lifestyle that emphasizes what makes a life personally worth living with establishing a livelihood beyond the orthodox sarariiman mode of work and life.

This paper aims to explore the meaning of relocation to places severely affected by the Great East Japan Earthquake such as Ishinomaki not only as examples of post-disaster reconstruction in Tōhoku, but as experiments that depart from the classic economic growth model, seek to establish novel lifestyles that combine the merits of the knowledge economy with the rural idyll, and develop models for improving life quality in other places as well. ${ }^{3}$ One resident in his 30 s sums up this idea by describing the present situation in Ishinomaki: 'Before the earthquake, everybody was somehow resigned in Ishinomaki that everything would stay the same or deteriorate, but since March 2011, hope has grown here that Japan may be changing'. ${ }^{4}$ This link between disaster reconstruction as an opportunity for setting the path for the future of Japan as a whole has also been made in other contexts ${ }^{5}$.

Drawing on and showing the limitations of urban studies scholar Richard Florida's notion of the 'Creative Class' ${ }^{6}$, this study approaches the phenomenon of post-disaster relocation to Tōhoku as an experimental playground for a generation which aspires to more self-determination, self-actualization, quality of life and generally a better work-life balance by creating new values and pursuing alternative lifestyles beyond the standard Japanese life course of continuous full-time employment. Many of

\footnotetext{
2 Interview on 3 August 2014.

3 Mano et al.,'Fukkō no case study', 196.

4 Ishinomaki Voice, Vol. 2 'Culture', 7.

5 Mitsubishi Comprehensive Research Laboratory, Shinsai Fukkō, 1-012, Samuels, 3.11, 30-32.

${ }^{6}$ Florida, The Rise of the Creative Class, 8.
} 
my interviewees match the criteria ascribed to the category of 'quiet mavericks' by Toivonen et al, i.e. determined individuals who find 'creative and integrative ways by negotiating conformist pressures tactfully' with the ultimate aim of 'engaging with society on their own terms', but also 'actively shaping social change' ${ }^{7}$. Florida's well-known argument is that attracting creative professionals constitutes a route to higher economic growth in the era of the knowledge economy ${ }^{8}$. In this study I describe the influx of creative individuals to Ishinomaki but also show that the majority of them hold post-growth incentives as motives for their relocation. It is a fact that non-regular company work (hiseiki shain) among those aged 15-24 has increased considerably in Japan after the onset of the millennium", catchphrases such as "crisis of youth", "unequal society" and "ice age of employment" featured in the media. But on the other hand many youth simply do not aspire to tenured company employment any longer ${ }^{10}$. This study explores the increased reliance of clearly post-materialist youth in contemporary Japan on open structures known as networks to minimize the effects of the structural instability in the labor market they are faced with.

Ishinomaki is at first sight a rather unremarkable harbor town of 150,219 inhabitants in Miyagi Prefecture ${ }^{11}$. Prior to the Great East Japan Earthquake, it had been known as an industrial center of fishery and fish processing, shipbuilding and pulp. If one looks at the statistical distribution of employment in Ishinomaki in July 2009 provided by the municipal government, out of 9072 enterprises altogether, the sectors with the highest numbers of employees were wholesale and retail trade (2895), accommodation industry and catering trade (1165), construction industry (1085) and services related to daily life and entertainment respectively (1051). ${ }^{12}$ In February 2012, the number of enterprises has decreased to 5300, the sectors with the highest numbers of employees being wholesale and retail trade (1412), construction (720), services related to daily life and

\footnotetext{
7 Toivonen, Norasakkunkit, Uchida, 'Unable to conform, unwilling to rebel?', 1-9.

8 Florida, The Rise of the Creative Class.

9 Goodman, Shifting Landscapes, 168.

10 Brinton, Lost in Transition, Chapter Six, Mathews and White (eds.), Japan's Changing Generations.

11 As compared to 163,000 before March 2011, Ishinomaki municipal homepage.

12 Ishinomaki City homepage.
} 
entertainment (486) and accommodation industry and catering trade (456). ${ }^{13}$

The increasing shift from labour-intensive industries to knowledge and technology based production as for example indicated in the dramatic decline of manufacturing from 972 to 399 enterprises had been ongoing from before the triple disaster and given rise to unemployment. This shift coupled with demographic changes is why Ishinomaki had faced an increasing number of abandoned buildings, downtown stagnation and inertia, as well as an overall lack of perspectives before the disaster. In other words, Ishinomaki is a case par excellence of a place where the disaster has hastened changes that had already been occurring as a result of wider forces at play. ${ }^{14}$ The damage inflicted by the earthquake and tsunami on the local economy is statistically evident: For example, the fishery catch before 3.11 had been decreasing from 166,719 tons in 2005 to 128,951 tons in 2010 . The overall catch dropped to 28,075 in 2011 but has returned to 86,288 tons in $2013 .{ }^{15}$ According to a report on the state of recovery issued by Ishinomaki City in June 2014 entitled "On the state of recovery since the Great East Japan Earthquake - Moving from a city devastated by disaster towards a global recovery model", at present the fishery processing industrial park operates at $65.5 \%$ of pre-disaster levels, with 55 companies remaining out of the original 84 (data as of March 2014).

After March 2011 Ishinomaki caught the attention of the media due to the enormous influx of approximately 240,000 volunteers coming from all parts of Japan, and even from abroad. For example, during the Golden Week holiday in 2011 a record number of 660 volunteers came to work with the non-governmental group Peaceboat in Ishinomaki. ${ }^{16}$ As the statement cited at the beginning of this paper shows, the town has started to attract long-term residents who have either chosen to give up their urban life and work to pursue a new lifestyle in Ishinomaki, or divide their time between Ishinomaki and Tokyo or environs. Exact figures on the number of newcomers are presently not available since some have not officially registered their residence card

\footnotetext{
13 Ishinomaki City Homepage.

14 Alexander, Natural Disasters.

15 Ishinomaki City Homepage.

${ }^{16} \mathrm{http}: / /$ peaceboat.jp/relief/reports/660-volunteers-during-golden-week-break-creating-a-new-base-for-vol unteers/ accessed on 7 January 2014.
} 
(juminhyō) in Ishinomaki despite in fact living there. Furthermore, the Ishinomaki City section in charge of population and migration does not provide details on the local origin or age group of newcomers on the grounds of privacy. NGO staff as well as former volunteers who have chosen to remain in Ishinomaki estimated some 100-150 migrants.

\section{Methodology}

This paper is based on four months of ethnographic research between March 2012 and August 2014 in Ishinomaki and other places in Tōhoku. I conducted participant observation as a volunteer with organizations such as Peaceboat and smaller NGOs, stayed in the 'Reconstruction Hostel' (see Figure 1), shared private accommodation introduced by Ishinomaki 2.0 with associates of 2.0 on Hiyoriyama mountain in Ishinomaki and did a homestay in downtown Ishinomaki in the summer of 2014. I attended numerous events of the 'Stand Up Week 2012' and 'Stand Up Week 2014', and carried out semi-structured and unstructured interviews with various individuals. Furthermore, I also volunteered as bar tender of the Reconstruction Bar (see for details later) with a colleague for one night in July 2013, donating the income to 2.0 as a modest sign of support. Data for this study also derive from qualitative interviews with forty respondents who had either migrated from urban areas to Tōhoku or engaged in a lifestyle between the disaster area and an urban area. Interviews usually lasted for 1.5-2 hours with follow-up interviews in some cases. All interviews were recorded and partly transcribed. Participants were found largely through snowball sampling, which due to the dense networks of newcomers turned out to be highly effective for identifying potential interviewees.

In retrospect, I underestimated the difficulty of emotional entanglement given that people were so eager to share their experiences of the disaster - although this pertains more to places such as Rikuzen Takata, where every other person I talked to had lost a direct relative in the disaster. Ishinomaki also suffered enormous human loss - more than 3,000 victims were counted, and more than 400 are still missing - yet compared to other places, Ishinomaki seemed to effuse hope and dynamism. It also took me a while to realize the subtle signs of suffering - many elderly male residents would rather go on with their lives than talk about what they went through. The situation in Ishinomaki partially confirms Das' argument about 'language giving way' in cases 
where victims' experiences were impossible to convey verbally. ${ }^{17}$ However, as for my fieldwork, once some familiarity and trust had been established, informants would hint at the emotional conundrum they were in. For example, a seemingly tough female bar owner in her late 30 s mentioned in a conversation in a matter of fact tone that, until then, she had felt 'too emotionally exhausted to have a relationship'. ${ }^{18}$ Such remarks sometimes caught me unprepared and I was at a loss how to respond. In general, respondents tended to try their utmost to revert to routine, and everything that helped them achieve this was appreciated.

Coming back to the issue of emotional entanglement: On the one hand, I felt at a loss as to what to say given the enormity of human suffering I encountered in accounts. 'Tense listening' - that is, 'waiting for the sound that calls for action', to borrow Kurt Singer's words ${ }^{19}$ - and simply expressing one's sympathy did not seem appropriate. I also kept wondering about how to compensate individuals for their generous accounts, much more than in usual fieldwork, given that these accounts entailed greater emotional content than was normally the case. It took me longer than usual to get sufficient distance from my fieldwork to be able to present my research at conferences. Whereas I sympathize with Das' point about the 'healing force of social anthropology', i.e. instrumentalizing one's discipline for the 'forming of one body, providing voice and touching victims, so that their pain may be experienced in other bodies as well', my take is that ultimately, to make a credible academic case, empathy and distance are required equally. ${ }^{20}$ At the risk of sounding smug, in some cases, the knowledge that one has an empathic listener seems to have an almost cathartic effect on those telling their stories; such verbal exchanges tend to take an emotional toll on the listener as much as it may be painful and cathartic for the person who shares his or her experience. Wherever I could, I sent gifts of items that seemed suitable or that individuals had mentioned they required. However, in retrospect, I realized that most informants appreciated, more than anything, the fact that I had visited Tōhoku, since my first stretch of fieldwork in mid-2012 came at a time when the Japanese and international media had largely

\footnotetext{
17 Das, Critical Events, 184.

18 Interview in May 2012.

19 Singer, Mirror, Sword and Jewel, 108.

20 Das, Critical Events, 196
} 
dropped the topic of the Great East Japan Earthquake from their agendas, and people in Tōhoku feared that they would be forgotten - an impression that was shared by numerous volunteers and volunteer project organizers I met on various occasions across Tōhoku. In retrospect, the fact that I did not encounter any of the 'hostile informants' Stevens described facing during her fieldwork with day laborers and volunteers at day laborer shelters ${ }^{21}$, i.e. 'people who had little interest in sharing information' with the fieldworker and 'actively despising the process of questioning for they saw it as invasive and manipulative ${ }^{22}$ must be in large part due to timing. When I returned to Ishinomaki for follow-up fieldwork in the summer of 2014, I was again fortunate enough to encounter individuals eager to speak and reflect on their experiences: a former engineer at the Onagawa nuclear reactor who eagerly attends events organized by Ishinomaki 2.0, a network formed by local and non-local youth after 3.11, but dismisses the volunteer group Peaceboat as not trustworthy; a female volunteer from Hokkaido who now works as a paid employee in a shop run by a former volunteer in downtown Ishinomaki and talks about her sense of appreciation of having been accepted by the local community but also mentions her hardship finding someone willing to rent a flat out to her; a local shop owner in her 70s who described her mixed feelings towards the many volunteers as gratitude for their efforts on the one hand and disinterest as a result of the lack of information about their present activities - to mention just a few.

\section{[Figure 1 approx. here]}

Figure 1: The 'Reconstruction Hostel' (Fukkō Minpaku) in an abandoned office building in central Ishinomaki. ${ }^{23}$

My fieldwork in Ishinomaki was dominated by the power of chance encounters to a far greater extent than my other experiences of fieldwork had been. Hendry has argued that 'serendipity' normally plays a role when doing participant observation, ${ }^{24}$

\footnotetext{
21 Stevens, On the margins, 14.

22 Stevens, On the margins, 14.

23 All pictures taken by the author.

24 Hendry, 'From Scrambled Messages to an Impromptu Dip', 55-70.
} 
and Kelly has written about the virtues of 'a radical serendipity, a kind of go-with-the-flow, seat-of-the-pants openness to the twists and turns of chance encounters $^{25}$ when conducting fieldwork-based research. However, in Ishinomaki, things happened on a daily basis at a speed that I had not experienced before. For example, a few days after my arrival, I was wandering around in central Ishinomaki looking for a place to eat lunch after several interviews. Standing in a square, I spotted a place that looked like a restaurant but did not have a sign saying it was open. Two elderly ladies were about to enter, so I rushed over and asked them whether the place was open. Although I was a complete stranger, they immediately invited me to join them. The owner of the restaurant later confided to me that he thought we were acquaintances since we entered together and sat at the same table. I ended up sharing the lunch with the ladies while listening to their firsthand experiences of the disaster and their views of the reconstruction process. I was struck by the inside of the restaurant: It was like entering, even intruding into, a private home. It turned out that the restaurant had been flooded by the tsunami - just like 46 percent of the entire city area had been inundated. The owner had subsequently decided to move his restaurant temporarily to his private kitchen and living room.

\section{Creating a new Ishinomaki: Local and non-local actors}

The influx of a large number of young non-locals to Ishinomaki created a positive atmosphere of change, renewal, and innovation in the immediate wake of 3.11. According to locals and newcomers in Ishinomaki, children were excited about being able to spend so much time together with their fathers in the immediate aftermath of the catastrophe; locals who had known one other but had never engaged in conversation became members of community networks. The disaster has brought heterogeneous people from various strata of society together, and issues that had previously not been discussed explicitly were aired. These developments confirm the 'extraordinarily generative character of disasters'. ${ }^{26}$ Furthermore, neighbors that had never spoken to each other started to greet one another, and new networks have been established in a previously shrinking city. One such newly founded network is 'Ishinomaki 2.0', a small

\footnotetext{
25 Kelly, review of 'Doing Fieldwork in Japan', 143.

26 Solnit, Paradise built in Hell, 22.
} 
group of approximately ten core members that consists of both locals and non-locals, although members from the greater Tokyo area constitute more than half the group. Most non-locals have professional backgrounds in architecture, design, advertising, and urban planning; local members are self-employed or have an NPO background. Ishinomaki 2.0 cooperates with American furniture manufacturer Herman Miller and has established a local furniture production studio called 'Ishinomaki Kōbo' (Ishinomaki Laboratory) that aims to create local jobs. ${ }^{27}$ Matsuzaki Ben, the managing director of Herman Miller Japan, pinpoints the key for sustained success to be the creation of local employment rather than mere creativity. ${ }^{28}$ The lab has increased its staff to six and markets its products across Japan and overseas. Recently, two university graduates from Yamagata and Sendai have started working in the furniture production studio and collaborations with the Mujirushi Ryōhin Netstore and Yahoo Japan are proof of the gradual professional expansion, increase in attractiveness and financial success.

According to its representative, Matsumura Gōta, the objective of Ishinomaki 2.0 is to create a new version of Ishinomaki through a grassroots movement with prospects for the young, closer communication between residents as well as among residents and non-locals, and a more open town in general. ${ }^{29}$ ' 2.0 ' has two meanings according to Matsumura. First, the term implies a version upgrade of Ishinomaki as a town, which implies that the group does not want simply to restore Ishinomaki to what it was, but rather convert it into something entirely new. ${ }^{30}$ Second, the name has echoes of 'Web 2.0', a term that describes the two-way nature of communication on Internet sites such as Flickr, sites that permit everybody to post messages, unlike previous forms of communication where there would be a side that communicated and one side that received messages.

The Ishinomaki 2.0 network has used abandoned spaces to set up ventures such as the above-mentioned 'Reconstruction Bar', a bar where locals and non-locals can meet in a relaxed atmosphere. The bar, which was designed by students from Musashino

\footnotetext{
${ }^{27}$ For details see: http://ishinomaki-lab.org/

28 Interview on 28 July 2014.

29 Matsumura in Nakamura, 3.11 tsukuru koto ga ikiru koto, A-188-9.

30 Matsumura, Ishinomaki Voice, Vol. 2, 24.
} 
Art University in Tokyo, led to the establishment of the 'Reconstruction Hostel' in September 2011 with the aim of providing discount accommodation to students and volunteers coming to Ishinomaki - with great success since the town had faced a lack of hotels until then (see Figure 1). In summer 2012, another project called 'Itonabu' (a neologism made up of 'IT' and 'manabu', i.e., 'to learn' in Japanese) was established in an abandoned shop with the idea of spreading IT knowledge among locals, especially children, raising education levels, and thus promoting business opportunities in Ishinomaki. $^{31}$

In addition, for four summers in a row, Ishinomaki 2.0 has organized numerous events known as 'Stand up Week', including music performances, outdoor film screenings, and flea markets, with stalls located at various places throughout the town so that visitors would be encouraged to get to know Ishinomaki better by walking from one stall to the next. Ishinomaki 2.0 has also started organizing walking tours (known as '2.0 excursions') through central Ishinomaki for interested groups, visitors, and tourists - a major change for Ishinomaki, which had never been known as a tourist destination. These excursions include unusual sites, such as the oldest adult cinema in Ishinomaki and Tōhoku (which is still operating), a visit to the local radio station with journalists telling their story of the earthquake, and other places that provide direct impressions of Ishinomaki's (sub-) culture, atmosphere, and history.

\section{[Figure 2 approx. here]}

Figure 2: Creative chaos inside the Ishinomaki 2.0 'Irori' shared office in central Ishinomaki.

Formerly a garage, the Ishinomaki 2.0 'Irori' office (see Figure 2) where Ishinomaki 2.0 members work, was restored and designed by Tokyo-based architect Ashizawa Keiji, and is filled with the minimalist wooden furniture made by Ishinomaki Laboratory. The shared office exudes a sophisticated urban atmosphere and serves as an open space and 'business café' 32 - anyone visiting Ishinomaki is welcome to use the

\footnotetext{
${ }^{31}$ For details see the 'Ishinomaki 2.0' homepage: http://ishinomaki2.com/category/project2/itonav/

32 For details see: http://ishinomaki2.com/v2/english/
} 
wireless LAN available there, have some coffee, or browse the books displayed on the shelves. During my initial stretch of fieldwork in May 2012, I spent considerable time there. It was not always clear who was 2.0 staff, who was a temporary volunteer or associate with the group, and who was a volunteer with some other group. Needless to say, I also met a great number of people there: student volunteers, project members as well as associates, project volunteers, and local supporters of the network. In retrospect, Irori may be one of these spaces with an 'environment that facilitates serendipity' (gūzen ga okiyasui kankyō). ${ }^{33}$ When I did follow up fieldwork in the summer of 2014, some of the disaster volunteers I had interviewed had chosen to remain in the area and had set up their own business or NGO projects.

\section{Interactions between local residents and newcomers}

'Isn't that kid doing something like volunteering? What's the point of getting together with such volunteers?" This is what residents in Ishinomaki have really been thinking. "Is that kid really OK quitting his work at his father's sushi place and moving into a new job with volunteers even if he seems to be making money? You are saying that you want to revitalize the city but the truth is that you have nothing to do, right? Looking for yourself? Having lost your job back home in the city?" This is what locals think about newcomers. We are in the countryside after all."

This no-nonsense description of how volunteers and networkers are perceived by local residents is an excerpt from an interview with the COO of Ishinomaki Kōbo. Chiba-san, who is 42 , was born and bred in Ishinomaki but has taken on a job with an enterprise that is perceived as being close to 'volunteers' as it is affiliated with Ishinomaki 2.0. Like numerous other local citizens, Chiba indicates that the network tends to be seen as the 'extension of a group of students engaging in club activities' because the core staff does not have any professional experience. Citizens in the central district where the network is located also criticize the communication style: A shop assistant in her early 40 s who is sympathetic to the network and has attended numerous activities points out that many events are announced at very short notice or not at all in the local community. She also indicates that recently, the network seems to have shifted its focus of attention

\footnotetext{
33 Serizawa, Tsukuru koto, 131.
} 
on attracting visitors from Tokyo rather than involving residents. ${ }^{34}$ Similarly, a local in her 50s describes the gap between emerging networks such as 2.0 and the local community as follows: "It is clear that with regard to the reconstruction process, we all have different speeds of walking. But it seems that despite the final goal being the same, Ishinomaki 2.0 is speeding off in a Mercedes whereas us locals are busy catching up on our bicycles.". ${ }^{35}$ An IT professional in his late 40s who is originally from Ishinomaki but works in Tokyo and comes back regularly to see his mother observes that despite his sympathy for new networks, he doubts the impact of short-term events: "Just remembering the sadness of the quiet streets in downtown Ishinomaki on the day after such events have ended..." ${ }^{36}$ In his view, the creation of local employment as for example in the case of Ishinomaki Kōbo contributes more to a sustainable revitalization of the city. On the positive side, small-scale projects such as the fashion show project Ishinomaki 2.0 member Iida Akio has carried out with local secondary school girls for Stand up Week 2014 are worth mentioning. According to Iida, the project aims to provide local youth with information and offer activities that are not provided at the local schools and thus broaden their horizons. For him, who works full-time in a high-paced marketing company in Tokyo, coming up to Ishinomaki for four days on average a month constitutes his 'life work'. ${ }^{37}$ In contrast to the anonymous materialist business world in Tokyo he appreciates the fact that through promoting personal contacts with local youth, he can see the immediate results of his activities and derives personal satisfaction from such collaboration.

\section{Emerging networks and alternative work/life models}

Richard Florida wrote about cities being 'cauldrons of creativity' 38 - a picture that is most appropriate for the state of creative hustle and bustle Ishinomaki finds itself in presently given the influx of up-and-coming individuals from various strata of society with innovative ideas, creative capital, and the courage to depart from extant beliefs and

\footnotetext{
34 Interview on 29 July 2014.

35 Interview on 4 August 2014.

36 Interview on 26 July 2014.

37 Interview on 2 August 2014.

38 Florida, Cities and the Creative Class, 1.
} 
'common sense' ${ }^{39}$. As early as the 1960s, Jane Jacobs elaborated on the contribution by newcomers to the diversity and creativity of communities. ${ }^{40}$ Nishida and Koizumi describe 'the emergence of civic pride' (shibikku puraido no jōsei) through the influx of non-locals in Ishinomaki, many of whom have started to perceive Ishinomaki as their 'second hometown' (dai-ni no furusato). ${ }^{41}$

Florida defined scientists, engineers, artists, musicians, designers, and knowledge-based professionals as the "creative class" ${ }^{42}$. Florida describes this group as individuals who engage in complex problem-solving that involves a great deal of independent judgment and requires high levels of education or human capital. Individuals that fit this category have recently been flocking to Ishinomaki. For example, not far from the Hiyori Kitchen introduced above and next to Ishinomaki 2.0's Irori office, a contemporary art gallery called the Hiyori Art Centre ${ }^{43}$ was opened in March 2012 by a curator from Yokohama. When I revisit Ishinomaki in the summer of 2014, however, the space has been closed, the curator having returned to Yokohama due to the expiration of funding. The gallery held regular exhibitions and offered artist residencies. Florida contends that cities that manage to attract the creative class tend to succeed in promoting economic growth and prosperity. If this is so, Ishinomaki could be on the way to the path of revitalization due to the numerous initiatives and projects that have been established. However, many promising projects eventually peter out as they face the harsh reality of financial viability. The irony, however, is that many individuals who are attracted to Ishinomaki or other places in Tōhoku harbor serious doubts about Japan's post-war path of economic growth and the capitalist system as a whole. Many consciously choose to opt out of their roles of being hapless cogs in a system that they do not believe in; others have not managed to secure one of the few highly competitive prestige jobs. But there are a number of highly educated graduates from elite universities with backgrounds in international development, law, urban planning,

\footnotetext{
39 Fuji, Chiiki wo kaeru sofuto pawā, 6-7.

40 Jacobs, The Death and Life of Great American Cities.

${ }^{41}$ Nishida and Koizumi, 'Shibikku puraido no jōsei ' in Mano, Nishida, Koizumi and Tane

'Fukko no case study', 212.

${ }^{42}$ Florida, The Rise of the Creative Class, xiii.

${ }^{43}$ For details see: http://hiyoriartcenter.com/about/
} 
business, architecture, and so forth, graduates who are in their mid-20s and have decided to move to Tōhoku to try out their ideas and set up social businesses and other creative endeavors. This study shares White's and Mathews' idea that historical generational change expresses itself in 'a vast array of individual choices and micro-interactions rather than through organized protest or even conscious generational solidarity ${ }^{44}$. According to 28-year-old Furuichi Noritoshi, author of Happy Youth in a Desperate Country, today, jobs may be less secure but people are living in the moment. "Now they are working for themselves, making their own decisions, taking their own responsibilities and reaping their own results. That's a major shift." 45 The emerging generation of Japanese youth differs fundamentally from previous generations where (male) company employees sacrificed themselves for the workplace and their sense of identity, if not purpose in life, essentially derived from work. ${ }^{46}$

Key terms that these newcomers tend to mention are 'quality of life', 'leisure', 'perspective', 'enjoyable', 'responsibility', 'contribution to the community', 'social business', and the notion of 'being part of a whole' rather than a professional individual with skills working for him- or herself. What unites them all, however, regardless of their attitude to pecuniary matters, is an emphasis on the maximization of enjoyment and the extremely casual dress code by Japanese standards - at least compared to standard company employees - no suits, no ties; just functional clothes, and often sportswear. This departure from traditional workplace behavior and shift to more casual attire and the inherent emphasis on merit and achievement regardless of one's educational or social background is also in line with Florida's description of the Creative Class and has been described as a way of expressing one's shifting identity during the process of transformative conversion. ${ }^{47}$

\section{Networks}

As most of those belonging to the Creative Class have less cash at their disposal than their peers in long-term jobs in urban areas, they rely heavily on networks with

\footnotetext{
44 White and Mathews, 'Epilogue' in Mathews and White (eds.), Japan's Changing Generations, 199.

45 Furuichi, cited in Pilling, 'Youth of the Ice Age', 2012.

46 Mathews, 'Ikigai and masculinity in today's Japan, 110-1.

47 Hoey, 'Grey suit or brown Carhartt'.
} 
like-minded individuals to make up for the lack of financial funds and exchange services.

An example is a 24-year-old male graduate from the prestigious Tokyo University called $\mathrm{X}$ here - who moved to Ishinomaki to set up a social business project with three like-minded peers on Oshika Peninsula some 45 minutes drive from Ishinomaki.

I am OK by myself, but I am involved in quite a lot of activities that I do together with everybody else, we have been organizing events, and I was planning many exchange activities with foreign students. The work I am doing now is just a result of this. I have always been interested in activities that involve various people and places and revitalization measures. In the long term, I would like to continue doing these kinds of activities that involve establishing relationships with all kinds of places (Boku ha betsu ni hitori de mo heiki nan desu kedo, minna to yaru no ga kekkō atte, mae kara ibento yattari, ryūgakusei to no kōryū kikaku mo daibu yatte, ima no shigoto mo sono enchōsen de [...] chigau hito to ba toka communityzukuri no katsudo ha zutto kyōmi ga atte ... chōkiteki ni shigoto ha ima no enchō de iroiro na tokoro ni hashi o kakete ikitai kedo). ${ }^{48}$

In September 2012, however, he moved to the United States to start a master degree at an Ivy League university, thus dropping out of the project. He says he is not interested in joining an elite manufacturing company, as previous generations would have been. Like many of his well-educated peers, he dismisses joining a company that offers secure employment and chooses insecure freedom instead. This is why, despite their very individualist lifestyles, they consider a network important since orthodox networks such as the company do not exist anymore. The members of the network do not only cooperate with regard to the daily implementation of the project, but they also live together in a shared flat (at least three of them prior to X's departure to the United States, although one member pursued a highly nomad lifestyle and did not live in the common flat all the time). $\mathrm{X}$ described the communication style between the network members as 'intuitive' in the sense that members know one another so well that they understand one

\footnotetext{
48 Interview on May 10, 2012.
} 
another without explicit verbalization and he hinted at his concern about a new member getting to know the communicative ropes. However, X's departure to pursue higher education abroad is just one example of the fluid state these individuals find themselves in, no matter how strongly elements of feeling and atmosphere are a source of bonding between members.

Another example is a 26-year-old former IT employee who was originally from Iwate Prefecture but has been working as a company employee in Tokyo for several years. After the earthquake, he returned to Iwate with funding from ETIC (Entrepreneurial Training for Innovative Communities) ${ }^{49}$ - an NGO that according to its homepage is 'working to produce opportunities and places for young people to develop their entrepreneurship and create innovation'. He remarks that after coming back to Iwate Prefecture, he noticed that despite the importance of professional skills, human beings are after all 'embedded in a network of social relations' (kankeisei no naka ni ikiru). ${ }^{50}$ Nevertheless, he perceives his work to be much more self-determined compared to his former job as a sarariman ('company employee') in Tokyo.

Intensive daily socializing - that is, working in the shared office, sharing lunch with collective orders of lunch boxes, group meetings, eating and drinking together during network events, sharing accommodation, going out for a drink at the Reconstruction Bar after finishing work, and even going on leisure trips together - goes hand in hand with active virtual communication on social media such as Facebook, Mixi and Twitter. Many of these network members therefore possess smartphones that they constantly check just like the urban nerds hanging out at T-site Daikanyama - the stylish Tsutaya bookstore and café complex that has attracted hipsters since its opening in December 2011. The amount of self-containment and privacy naturally varies according to the network; yet, with Ishinomaki 2.0, members share considerable time together. After pursuing project activities in the shared 2.0 office, they hang out in the 2.0 bar before going home to the accommodation shared with other 2.0 members. When one of the 2.0 members chats up the girl next door, the entire 2.0 community will know about it within a few hours. If the chat up does not work, 2.0 members may consider

\footnotetext{
${ }^{49}$ For details see: http://www.etic.or.jp/

${ }^{50}$ Interview on 13 August 2012.
} 
taking part in a machikon event, i.e. a matchmaking event organized by 2.0 to promote regional revitalization. The combination of an elevated sense of responsibility, more reflection on what constitutes a fulfilled life and work, self-containment, and networking could be described as the characteristic of these emerging networks of locals and newcomers to Tōhoku and of post-growth society in contemporary Japan as such.

"It's all holiday and work at the same time." - On the increasing convergence of work and leisure

In this section I will discuss the increasing blurring of work and leisure as a feature that characterizes the lifestyle of most newcomers depicted here. I suggest that this phenomenon is related to a sense of strategy which in turn is a result of increasing insecurity on the labor market as also evident from Amano's statement cited at the beginning of this paper. On the one hand, the majority of the new settlers work on freelance projects that they have largely created for themselves. Thus, identification with work tends to be much stronger than with company employees. On the other hand, newcomers often find it difficult to switch to a leisure mode of life despite their initial concern for a greater life quality. For example, one 2.0 network member concedes that his own lifestyle does not match the message that the network promotes about making a better city and living alternatively ${ }^{51}$. Due to the amount of work he faces he does not have the time available to enjoy Ishinomaki. These findings are in line with Kato's hypothesis about the interrelation of work and self in Japanese youth abroad. ${ }^{52}$

What distinguishes the networks in Ishinomaki from other 'tribes' across Tōhoku is their familiarity with one another, their backgrounds and activities. This is partly due to regular events, often held in a PechaKucha event style - 20 slides being shown for 20 seconds each, allowing presenters to outline their activities, projects, and message in a very concise and fast-paced format. The PechaKucha Night format, which usually features 8 to 14 such presentations, was conceived by architects Astrid Klein and Mark Dytham in February 2003 in Tokyo, and has since spread successfully all over

\footnotetext{
51 Interview on 3 August 2014.

52 Kato, 'True Self, True Work', 51-2.
} 
the world. Thus, in summer 2012, for example, Ishinomaki 2.0 organized an event focusing on the power of women in Ishinomaki in a local snakku (i.e., a bar-like establishment), which was a huge success since it managed to attract both active local women as well as non-local architects, designers, marketing employees, emerging social business entrepreneurs, and so forth (see Figure 5). The PechaKucha format is usually associated with presenters from the disciplines of architecture and design as well as academia - an echo of Florida's 'Creative Class'. Such events allow newcomers to Ishinomaki to meet and exchange with like-minded peers in an effective manner while enjoying themselves in the sense of it being a 'creative experience' ${ }^{53}$ I contend that this combination of leisure and business in casual and often rather unorthodox surroundings is a common feature of network activities. Participant observation and interviews suggest that for numerous members of emerging networks, a growing lack of strict separations that previously demarcated leisure and work as well as private and public domains constitutes a typical feature of their experiential lifestyles.

This is exemplified in the statement of another 26-year-old male graduate from a prestigious university in Tokyo who gave up his well-paid consulting job in Tokyo and moved to Ishinomaki to set up a social business:

Before, when I was employed in the consulting company, work and my private life were entirely separate ... although I have to say that my private life was pretty much invaded by my work ... now there is no such clear line ... when I go somewhere on an appointment it is work, but I also get wonderful stuff to eat ... and this is really important ... saying it in comprehensible terms, before I was always thinking 'when will it be Friday so that I can get some rest' ... just like all the corporate employees are waiting for Saturday. I think I live a really healthy life just by not thinking in that way and having control over my life. Sometimes I regret things, for example having slept in too late, e.g. getting up at $8 \mathrm{am}$ and going to bed at 1 or $2 \mathrm{am}$. Now I do not have days off. Is today Sunday? I really have no idea ... I really like this idea of spending the days without thinking about. ${ }^{54}$

\footnotetext{
53 Florida, The Rise of the Creative Class, 13.

${ }^{54}$ Interview on 29 July, 2012.
} 
The 26-year-old former IT employee from Iwate Prefecture with professional experience in Tokyo mentioned above is now working to improve the IT environment for locals in kasetsu ('temporary') facilities. He observes that, compared to his former work as a company employee, he is now more emotionally attached to his work, sometimes working on weekends, too, but earns $20 \%$ less than previously. He adds that there is less separation between private and professional activities now, but also remarks that he spends less time watching television and surfing the Internet, and indicates that his life is much more fulfilling now, especially in social terms.

In April 2012, another 24-year-old university graduate in international development cooperation from Tokyo with experience in Cambodia moved to a small hamlet that is an administrative part of Rikuzen Takata in Iwate Prefecture. It has been fifty years since a new resident has been registered in the remote hamlet. For work, he offers IT courses for mostly female residents twice a week and coordinates visits to the region by non-locals, but he also engages in volunteer activities and travels regularly across Japan to give lectures about his experience. In his words, 'Life and work are all mixed up. I work, enjoy myself, do volunteer work. I am not sure whether my life is balanced, but I enjoy everything - it's all holiday and work at the same time.'55

Talking poignantly about his present life compared to his former career as an employee of a design company in Tokyo, a 29-year-old representative of a newly established NPO in Rikuzen Takata says, 'Life is really hard now compared to before; however, life is so great now (shinu hodo taihen ima no hō ga, shinu hodo tanoshii)', adding that he could not imagine going back to his former job as a paid company worker, despite the security that came with it. ${ }^{56}$

To sum up this section, we could conclude that beyond MacCannell's argument that lifestyles should be seen as "combinations of work and leisure...replacing 'occupation' as the basis of social relationship formation, social status and social

\footnotetext{
55 Interview on 29 July 2012.

56 Interview on 5 August 2012.
} 
$\operatorname{action}^{57}$, this emergent generation of Japanese youth pursue a lifestyle that combines a relatively big degree of individual discretion ${ }^{58}$, less emphasis on material concerns with a highly advanced degree of convergence of work and leisure. Instead of 'seeking refuge in the realm of leisure' 59 , these individuals are seeking refuge in the realm of work and leisure - i.e. work is considered largely equivalent with leisure.

\section{Temporary "small-scale happiness" and process orientation}

Apart from the above-described living mode of converged work and leisure, another remarkable characteristic often found in group projects is the 'temporary lifestyle', as Ishinomaki 2.0 representative Matsumura Gōta mentioned in a PechaKucha presentation in July 2012, when he advocated a lifestyle that emphasizes living for the moment rather than long-term planning. This resembles the 'all we want is fun for now' (ima, tanoshikereba ii janai) attitude described by Fukushima, ${ }^{60}$ as well as the emphasis that Furuichi ${ }^{61}$ claims today's youth put on 'small-scale happiness'. In a similar vein, at the same PechaKucha event, Peaceboat employee Kobayashi Shingo talked about his interest in the process and the relations that emerge between people involved in reconstruction projects. Meanwhile, a social business entrepreneur in his late 20 s, when asked about the planned duration of his project, replied as follows:

We do not think about what things will be like in one year, we have no idea whatsoever. I guess the best option for the fishermen we work with is if they resumed their original work, i.e. removing the shells of oysters. Things turn out different as a result of changes in the environment. If what we are doing is needed occasionally, we would like to keep on doing things; if people want to go back to the sea to work, then that's fine too. ${ }^{62}$

\footnotetext{
57 MacCannell, The Tourist, 6.

58 Putnam, Bowling Alone, Weiss, 'Parallel universe', Zukin, Landscapes of power.

59 MacCannell, The Tourist, 6.

60 Fukushima (sole author for Chapter 1) and Ishitani, Nihon no wakamono ha fukō janai, 44-45.

61 Furuichi, Zetsubō no kuni no kōfuku na wakamonotachi, 104-5.

62 Interview on 29 July 2012.
} 
One volunteer group organizer in his early 30 s from Osaka lived in a tent in Ishinomaki for the first few months after the disaster, but moved into the building where the Reconstruction Bar is located in summer 2012. He says that the furniture he uses is all DIY and the atmosphere is warm and cozy as a result. Having obtained some privacy after abandoning tent life, he says feels like having adopted 'a somewhat more sedentary lifestyle'. ${ }^{63}$ Asked about how long he intends to stay in Ishinomaki or what his plans are for the next few years, he smiles saying that he does not really know. ${ }^{64}$ When I revisit Ishinomaki in the summer of 2014, he is still there. He is part of a successful revitalization project on the Oshika Peninsula, but plans to open a restaurant in Tokyo in the near future. As for the meaning of his activities to himself, he describes his role as 'a person bringing in fresh air' (kaze no hito), which suggests temporary impact but also implies a certain sense of nomad liminality. ${ }^{65}$

This attitude of perpetual transformation as shown in the motto 'let's see how things turn out' seems typical in the majority of newcomers and volunteers, regardless of the duration of their stay in Tōhoku. As illustrated by our first lifestyle migrant introduced at the beginning of this paper, Amano-san, many of these networkers pursue experiential work and lifestyles that focus on the present and on creative experiences - the here and now - since there are too many variables to make any kind of prediction feasible. Interestingly, however, many of these network members do not seem to perceive this lack of long-term (or even mid-term) planning as a downside. Similarly, another temporary mover in his late 20 s who is a graduate from a top university in Tokyo and now works as a social entrepreneur laughs when I ask him about his long-term career plans, asking me "Any suggestions?" On a more serious note, the sense of insecurity as the dominant attitude in freeters has severely afflicted their desire to commit to relationships or produce offspring. ${ }^{66}$

Many of these newcomers and volunteers openly dismiss the emphasis of mainstream Japanese society on stable, secure jobs, determined work routines, and material values (although the last point does not apply to all of them). In the terms of

\footnotetext{
63 Cited in the free paper Ishinomaki Voice, 16.

64 Interview on 20 July 2012.

65 Interview on 4 August 2014.

66 Coulmas, Population Ageing and Decline in Japan, 133.
} 
previous generations, Japanese youth today are refusing to become full-fledged members of 'the adult social order' and avoid 'adult commitment' ${ }^{67}$. Instead, they have chosen to pursue distinctly different lifestyles that involve self-determined simultaneous engagement in several endeavors (some of which are unpaid), attempts to cut down on expenses by engaging in DIY, as well as the sharing and exchanging of things in the form of shared offices and shared living spaces - in other words, a creative lifestyle that is more about rediscovering the local by using vacant spaces. Ishinomaki 2.0 members repeatedly present themselves as a counterculture to the 'Aeon suburbia model', advocating downtown (derelict) Ishinomaki as a 'space of experimentation' (jikken-jō) and declaring as its mission 'to attract people (from outside) in order to turn Ishinomaki into an open town brimming with creativity (Ishinomaki 2.0 no mission ha 'open de sōzōsei ni michita machi o tsukuru koto' de aru ga, sore o jitsugen shiteiku shudan ha 'hito no yūchi' to iu keyword de kataru koto ga dekiru)' ${ }^{68}$ - a message that has resulted in an influx of urban newcomers and short-term visitors since 2011.

Whereas the migration or rather: temporary mobility ${ }^{69}$ described here may not fall into the classical category of 'crisis counterurbanisation' as described by Gkartzios $^{70}$, the overall lack of attractive work and life perspectives in urban areas could be perceived as an extended 'crisis' and the focus of contemporary youth on the short term could be considered as crisis management. Similarly, a female freeter ('part-time worker') from Nagoya, aged 29, whom I interviewed at a volunteer information fair at the Tōhoku University in Sendai on March 11, 2012, explained that she had been 'living a volunteer life even outside of the disaster area for three years' and that she 'relocated to Tōhoku after the disaster', adding that 'working as a volunteer allows her to live a life without having to earn a steady income' and that 'she has been

\footnotetext{
${ }^{67}$ Mathews and White (eds.), Japan's Changing Generations, 6.

${ }^{68}$ Ishinomaki Voice, 24.

${ }^{69}$ Human geographer Janoschka argues that lifestyle migrants should not be classified as migrants at all since "many supposed migrants do not migrate permanently but can be considered rather as seasonal or temporary movers." (2009) I agree that most of my interviewees do not fall into the categories of 'migration' or 'residential stability' and should thus not be referred to as 'migrants' but rather temporary movers.

70 Gkartzios, 'Leaving Athens'.
} 
living on the love of people only'. ${ }^{71}$ While this life model could be taken as seeking refuge from orthodox employment by aspiring to making a livelihood without regular work, the fact that the informant mentioned having to do irregular low-paid baito work in convenience stores between volunteering demonstrates the reality of material constraints also on individuals hoping to escape from them. On the other hand, previous research has demonstrated that individuals who do not have career-track jobs, also known as furiitaa, seem happier in their working lives than are regular workers ${ }^{72}-\mathrm{a}$ finding that matches my empirical data obtained during fieldwork for this study.

\section{[Figure 3 approx. here]}

Figure 3: 'Stand Up Week' 2012: sharing and listening to memories about the history of Ishinomaki in the community center 'Kameshichiya' founded in March 2012 in central Ishinomaki.

\section{[Figure 4 approx. here]}

Figure 4: 'Stand Up Week' second-hand book market in the kasetsu 'Fureai Shōtengai' [Shopping Mall of Encounters] in central Ishinomaki.

\section{[Figure 5 approx. here]}

Figure 5: Ishinomaki 2.0 representative Matsumura Gōta and architect Nishida Osamu welcoming guests at the 'Stand Up Week' 2012 PechaKucha event in a local bar to discuss and celebrate Ishinomaki's women's power (joshi pawā) in central Ishinomaki.

\section{Conclusion}

The recent developments in Ishinomaki and other towns in Tōhoku described above merit scrutiny: the influx of newcomers that could qualify as Florida's "Creative Class" coupled with the emergence of innovative ideas and networks and the overall transition

\footnotetext{
71 Interview on March 11, 2012. See Klien, 'Disaster volunteers’ for narratives of disaster volunteers.

72 Mathews, 'Seeking a career, finding a job' in Mathews and White (eds.), Japan's Changing Generations, 131.
} 
of Ishinomaki from a focus on production to 'multi-functional' ${ }^{73}$ creativity has brought in some fresh air. For example, according to the Itonabu brochure, one of the local pupils indicates that as a result of attending the IT lab regularly, he rethought his professional future and decided to attend university rather than apply for a job after high school in order to realize his dream of becoming an IT programmer. He points out that he has learned how to study for himself and says that he is really happy to have gone on to university. While such personal stories are bound to enforce the transition of Ishinomaki to a knowledge-based economy, it remains to be seen, however, whether the experiments being carried out now will result in long-term changes of the local economy or Japanese society as a whole. An issue that needs to be addressed urgently is making emerging networks better known among residents by getting more of the local youth involved, such as the fashion show project mentioned above. At present, most of the members of Ishinomaki 2.0, for example, are from Tokyo. As a result, many networks are better known nationwide or even abroad than among Ishinomaki residents. In a similar vein, an organizer of a variety of reconstruction projects in Kamaishi observes that before March 2011 he was busy initiating revitalization activities among locals, but after the disaster, he has dedicated his time almost exclusively to activities that involve exchange with non-locals, coordinating volunteers, and organizing tours for non-locals. ${ }^{74}$ This shift from local to translocal activities can be observed all over the Tōhoku region in the aftermath of the Great East Japan Earthquake. Furthermore, the developments described above point to the emergence of 'the new public sphere' (atarashii kokyo), as Yamashita put it, i.e. a new kind of civil society shaped by citizens at the grassroots level. ${ }^{75}$

As for Ishinomaki's recent development, given the vibrant atmosphere, the rising numbers of well-educated and highly motivated newcomers to the area, and the inspiration and ideas they bring, the potential for sustainable change is there. Post-disaster recovery has been interpreted as return to normalcy by some, be it in a social, economic or emotional sense; others define recovery as an opportunity for radical reform or an ongoing "search for a "new normal"" in the sense of rebuilding a

\footnotetext{
73 Wilson, 'The spatiality of multifunctional agriculture'.

74 Interview on 5 August 2012.

75 Yamashita, 'Public Anthropology of Disaster', 23.
} 
better city. ${ }^{76}$ Mileti claims that post-disaster reconstruction should be defined as not as a solely physical restoration in the sense of replacing the shattered built environment, but essentially a social process that 'encompasses decision-making about restoration and reconstruction activities'. ${ }^{77}$ Oliver-Smith has pointed out that 'disaster reconstruction is fraught with ambivalence' as a result of communities being torn between the aspiration to reestablish stability and continuity and the need for change. ${ }^{78}$ Ishinomaki has seen social change in many ways described in this paper, but it is a fact that some of the dynamic and even radical atmosphere immediately after the disaster has been replaced with a return to everyday life and issues. A local affiliate with Ishinomaki 2.0 in his early 40 s observes that "right after the disaster everyone got on well. After the disaster all kinds of people came to Ishinomaki and the atmosphere was really good. Now it seems we are going back to the pre-disaster ways of Ishinomaki: heckling, jealousy, deception.". ${ }^{79}$ The long-term success of the networks described above will depend on the extent of local support. Greater understanding among residents can only be ensured by providing information about ongoing activities to the local community, truly involving residents in the planning and implementation of projects and attracting locals with high social skills as well as experience of living outside Ishinomaki who thus possess both an internal and external view of the town. Whereas this study has referred to Florida's notion of "creative classes", the empirical data obtained in Ishinomaki, Miyagi Prefecture, shows that despite the influx of "creative people" and the economic growth that may result from it, the majority of newcomers have relocated for post-growth incentives such as a better life quality and more self-determination with regard to work. Thus, this case study highlights the limitations of Florida's focus on creative capitalism as an economic driving force in the $21^{\text {st }}$ century ${ }^{80}$. Nevertheless, Florida's paradigm is relevant for analyzing the modes of living and working of networkers in Ishinomaki in the sense that these temporary movers clearly fit into the social milieu of knowledge workers, artists and intellectuals

\footnotetext{
76 Vale and Campanella, eds, The resilient city, 11.

77 Mileti, Disasters by design, 220-30.

78 Oliver-Smith, 'Anthropological Research', 313.

79 Interview on 4 August 2014.

80 Florida, 'Cities and the Creative Class'.
} 
whose job is 'to create meaningful new forms ${ }^{\text {" } 11}$. Furthermore, lifestyle choices such as participation in a variety of experiential activities and casual attire in everyday (working) life also make newcomers to northeast Japan appear as fitting into Florida's category. However, rather than spurring economic growth in the way Florida suggests, I contend that the fundamental doubts which the majority of these newcomers hold about a growth-oriented society and the structured instability of the labor market make them envisage modes of life that emphasize sustainability, small-scale activities at the local level rather than putting priority on economic growth. Nevertheless, some of these ambitious young individuals find themselves constrained by financial pressures and work and life patterns that resemble those of conventional company employees. Furthermore, since the majority of projects started by newcomers are still in their incubation period and there is a time lag in statistical documentation provided by the municipal government, it is too early to draw any conclusions about the economic impact of the individuals who have relocated to Tōhoku. This study reveals the strategic nature of temporary networks regardless of the nonchalant coolness and emphasis on the here and now networkers like to show. I have depicted how individuals hedge their bets by joining a variety of networks as well as engaging in individualism. I have hence simultaneously unraveled the workings of the neoliberal labor market with regard to the strategic ephemerality that can be inferred from such communities. Ultimately, the paper provides ethnographic evidence of Japan's ongoing departure from the postwar "salaryman" labor system towards more flexible, but insecure and precarious work patterns and the resulting inconsistencies contemporary youth are faced with in their daily lives. Findings show individuals mostly in their 20s and 30s striving to bridge the gap between their growing prioritization of values such as personal satisfaction, purpose in life, self-actualization and self-determination and a lack of clear long-term opportunities as a result of the structurally instable labor market by opting to live and work for the moment. This study also shows that the post-disaster situation in Ishinomaki allows some urban young individuals to experiment with new lifestyles, both because they have the financial resources or infrastructure available to do so and because of the moral meaning that they derive from their activities. In sum, post-disaster developments in Ishinomaki can be seen as progressive in the sense that some local

\footnotetext{
81 Florida, The Rise of the Creative Class, 8.
} 
employment has been created, new projects and start-ups keep emerging and a partial change of atmosphere has been achieved. However, the narratives presented above elucidate sociospatial inequalities and confirm Amin's claim that 'proximity [of heterogeneous individuals] on its own is not enough to bring about social transformation'. ${ }^{82}$ Only time will show whether a critical mass can be reached to make these first steps for change sustainable by convincing the local community of the merits of cooperating with newcomers and truly forge a civic culture ${ }^{83}$ out of the above-described encounters between heterogeneous actors in the mid and long term.

\section{Acknowledgments}

I have presented versions of this paper at various conferences over the past years. I would like to express thanks to those who provided insightful comments that have improved the paper. I would also like to express gratitude to John W. Traphagan for providing constructive comments on an earlier version of this manuscript. I am deeply indebted to numerous residents of Ishinomaki, especially to Mr. Suda Masahiro (Apricot), Mr. and Mrs. Yonekura at Kameshichiya, Ishinomaki 2.0, Aizawa Shōten, Abe Kiyoko, Uotani Hiroshi, DJ Bero (Stereograph), and Abe Akira (Romantei). I would also like to thank Mr. and Mrs. Wada (P \& A), Kobayashi Shingo (Peaceboat), as well as Tsumugiya and the members of Megumi Japan. Furthermore, I am indebted to Save Takata, Iwate Fuxing Collaboration Center (Iwate Renkei Fukkō Sentāa), Takasawa Jushoku (Koshoji, Rikuzen Takata) and numerous volunteers and social entrepreneurs in the Rikuzen Takata, Kesenuma and Kamaishi area who generously allowed time for questions.

\section{References}

Aldrich, Daniel P., Building Resilience: Social Capital in Post-Disaster Recovery.

Chicago and London: The University of Chicago Press, 2012.

Alexander, David, Natural Disasters. New York: Chapman and Hall, 1993.

\footnotetext{
82 Amin, 'Ethnicity and the multicultural city.'

83 Valentine, 'Living with difference': 323.
} 
Amin, Ash, 'Ethnicity and the multicultural city: living with diversity', Environment and Planning A34, 2002: 959-80.

Brinton, Mary, Lost in Transition: Youth, Work, and Instability in Postindustrial Japan. Cambridge: Cambridge University Press, 2011.

Castells, Manuel, The Rise of the Network Society. Oxford: Blackwell, 2000.

Castells, Manuel, 'The Network Society: From Knowledge to Policy' in Castells, Manuel and Gustavo Cardoso, eds, The Network Society: From Knowledge to Policy. Johns Hopkins Center for Transatlantic Relations, Washington, D.C. 2003, 3 -21 .

Coulmas, Florian, Population Decline and Ageing in Japan - the Social Consequences. London and New York: Routledge, 2007.

Das, Veena, Critical Events: An Anthropological Perspective on Contemporary India, Delhi: Oxford University Press, 1995.

Edgington, David W., Reconstructing Kobe: The Geography of Crisis and Opportunity. Vancouver, BC, Canada: University of British Columbia, 2010.

Florida, Richard, The Rise of the Creative Class: And how it's transforming work, leisure, community and everyday life. New York: Perseus Book Group, 2002.

Florida, Richard, 'Cities and the Creative Class', City \& Community 2:1 (March 2003): $3-19$, http://uv.vuchorsens.dk/r/KAZ/Undervisning\%202012-2013/GEOLOGI/Bæredygtighed /Befolkning\%20og\%20bæredygtighed/GetFile.pdf (accessed 7 January 2014).

Florida, Richard, Cities and the Creative Class. New York and London: Routledge, 2005. 
Fuji Hiroshi, Chiiki o kaeru sofuto pawā [Soft Power that Changes the Region]. Tokyo: Seigensha, 2012.

Fukushima Maiko and Ishitani Masaki, Nihon no wakamono ha fukō janai [Japanese Youth is not Unhappy]. Tokyo: Sofuto Banku Shinsho 153, 2011.[Fukushima Maiko, Chapter 1: Nihon no wakamono ha fukō desu ka? 13-72]

Furuichi Noritoshi, Zetsubō no kuni no kōfuku na wakamonotachi [Happy Youth in a Desperate Country]. Tokyo: Kōdansha, 2011.

Gill, Tom, Brigitte Steger and David H. Slater, eds, Japan Copes with Calamity: Ethnographies of the Earthquake, Tsunami and Nuclear Disasters of March 2011. Oxford, Berlin, Brussels, Frankfurt am Main, New York, Vienna: Peter Lang, 2013.

Gkartzios, Menelaos, 'Leaving Athens': Narratives of counterurbanisation in times of crisis', Journal of Rural Studies 32 (2013): 158-167.

Goodman, Roger, 'Shifting Landscapes: The social context of youth problems in an ageing nation' in Roger Goodman, Yuki Imoto, Tuukka Toivonen, eds, A Sociology of Japanese Youth: From returnees to NEETs. Nissan Institute/Routledge Japanese Studies Series, London / New York: Routledge 2012, 159-173.

Hasegawa Hiroki and Yamazaki Ryō, eds, Tsukuru koto, tsukuranai koto - machi o omoshiroku suru 11-nin no kaiwa [Making, Not Making - Conversations with 11 People Who Make Places Interesting]. Kyoto: Gakugei Shuppansha, 2012.

Hendry, Joy, 'From Scrambled Messages to an Impromptu Dip: Serependity in Finding a Field Location', in Ted Bestor et al., eds, Doing Fieldwork in Japan. Honolulu: University of Hawai'i Press, 2003, 55-70.

Herslund, Lise, 'The Rural Creative Class: Counterurbanisation and Entrepreneurship in the Danish Countryside', Sociologia Ruralis, 52: 2 (April 2012): 235-255. 
Hetherington, Kevin, Expressions of Identity: Space, Performance, Politics. London, Thousand Oaks, New Delhi: Sage, 1998.

Hoey, Brian, 'Grey suit or brown Carhartt: Narrative Transition, Relovation, and Reorientation in the Lives of Corporate Refugees', Journal of Anthropological Research 62:3 (Fall 2006): 347-371.

Igarashi Taro, ed., 3.11/After: Kioku to saisei he no purosesu [3.11/After: The Process of Memory and Reconstruction]. Tokyo: LIXIL shuppan, 2012

Iida Akio, Tokyo Institute of Technology, Daigakuin Shakai Kōgaku Senkō Mano Laboratory, Mano Yōsuke, Watanabe Kyōko, and Nomura Miri, eds, Ishinomaki Voice, Vol. 2: 'Culture', April 2012.

Ishinomaki City Homepage, http://www.city.ishinomaki.lg.jp/cont/10102000/0040/2204/2204.html (accessed on 10 September 2014).

Ishinomaki City Homepage, http://www.city.ishinomaki.lg.jp/cont/10102000/0040/3914/4-4-2-1109.pdf (accessed on 12 September 2014).

Ishinomaki City Homepage, http://www.city.ishinomaki.lg.jp/cont/10102000/0040/3914/20130301161642.html) (accessed on 12 September 2014).

Jacobs, Jane, The Death and Life of Great American Cities. New York: Random House, 1961.

Janoschka, Michael, 'The contested spaces of lifestyle mobilities: Regime analysis as a tool to study political claims in Latin American retirement destinations', Die Erde 140:3 (2009): 251-74. 
Kato, Etsuko, 'True Self, True Work: Gendered Searching for Self and Work among Japanese Migrants in Vancouver, Canada', Japanese Review of Cultural Anthropology, Vol. 11, 2010: 47-66.

Kelly, William, review of 'Bestor, Steinhoff, and Bestor, eds., Doing Fieldwork in Japan', Journal of Japanese Studies, 31:1 (2005): 141-145.

Klien, Susanne, 'Katastrophenvolunteers in Tohoku: Lebensinhalt, Strategie, Selbstzufriedenheit' (Disaster Volunteers in Tohoku: Purpose in Life, Strategy, Self-Complacency?) in German Association for Social Science Research on Japan, ed., German Association for Social Science Research on Japan Yearbook 2013: 255-274.

MacCannell, Dean, The Tourist: A New Theory of the Leisure Class. Berkeley: The University of California Press, 1996

Maffesoli, Michel, The Time of the Tribes: The Decline of Individualism in Mass Society. London, Thousand Oaks, and New Delhi: Sage, 1996.

Mano Yōsuke, Nishida Osamu, Koizumi Yoichi, and Tane Tsuyoshi, 'Fukkō no case study', in Igarashi Tarō, ed., 3.11/After: Kioku to saisei no purosesu [3.11/After: Processes of Memory and Reconstruction]. Tokyo: LIXIL Shuppan, 2012, 194-217.

Matanle, Peter, 'The Great East Japan Earthquake, tsunami and nuclear meltdown: towards the (re)construction of a safe, sustainable, and compassionate society in Japan's shrinking regions', Local Environment, Vol. 16, No. 9, October 2011: 823-847.

Mathews, Gordon, 'Can 'a real man' live for his family? Ikigai and masculinity in today's Japan' in James E. Roberson and Nobue Suzuki, eds, Men and Masculinities in Contemporary Japan: Dislocating the salaryman doxa. London and New York:

Routledge 2003: 109-125.

Mathews, Gordon and Bruce White, eds., Japan's Changing Generations: Are young people creating a new society? London and New York: Routledge, 2004. 
Matsumura, Gōta, 'Ishinomaik 2.0/Atarashii Ishinomaki wo tsukuru' (Talk session) in Nakamura, 3.11 tsukuru koto ga ikiru koto, Wawawa Project: Tokyo, A-188-201.

Matsumura, Ishinomaki Voice, Vol. 2: 'Culture', 24

Mileti, Dennis S., Disasters by design: A reassessment of natural hazards in the United States. Washington, D.C.: Joseph Henry Press, 1999.

Mitsubishi Sougou Kenkyujo [Mitsubishi Comprehensive Research Laboratory], ed., Shinsai Fukkō to Nihon no mirai [Disaster reconstruction and Japan's future]. Tokyo: Maruzen, 2013.

Nakamura, Masato, 3.11 tsukuru koto ga ikiru koto - Higashi Nihon Daishinsai fukkō shien purojekuto [Making Things Is Living - Great East Japan Earthquake Reconstruction Support Projects]. Tokyo: Shinano Publishing Press, 2012.

NPO Hōjin ETIC, Chiiki shigotozukuri [2012 February] Jissengata Internship,

Jireishuu 2011 [Making Regional Work - Challenge Internship Report, February 2012]. Tokyo: Minami no Kaze-sha, 2012.

Oliver-Smith, Anthony, 'Anthropological Research on Hazards and Disasters', Annual Review of Anthropology 25, 1996: 303-28.

Pilling, David, 'Youth of the Ice Age', Financial Times, 6 July 2012.

Putnam, Robert D., Bowling alone: The collapse and revival of American community. New York: Simon \& Schuster, 2000.

Samuels, Richard J., 3.11: Disaster and Change in Japan. Ithaca, New York: Cornell University Press, 2013.

Serizawa Takashi, 'Guest 07, Conversation with Hasegawa', in H. Hasegawa and R. 
Yamazaki, eds, Tsukuru koto, Tsukuranai koto: Machi wo omoshiroku suru juichinin no kaiwa [Making, not making things: Conversations with eleven individuals who make places more interesting], Kyoto: Gakugei Shuppan 2012: 125-138.

Singer, Kurt, Mirror, Sword and Jewel: A Study of Japanese Characteristics. New York: Japan Library, 1997.

Solnit, Rebecca, A Paradise Built in Hell: The Extraordinary Communities that arise in Disaster. New York: Penguin Books, 2009.

Stevens, Carolyn S., On the margins of Japanese society: Volunteers and the welfare of the urban underclass. London and New York: Routledge, 1998.

Toivonen, Tuukka, Norasakkunkit, Vinai, Uchida, Yukiko, 'Unwilling to conform, unwilling to rebel? Youth, Culture and Motivation in Globalizating Japan', Frontiers in Cultural Psychology, Volume Two, Article 207, 2011.

Vale, Lawrence J., Campanella Thomas J., eds, The resilient city: how modern cities recover from disaster. New York: Oxford University Press, 2005.

Valentine, Gill, 'Living with difference: reflections on geographies of encounter', Progress in Human Geography 32:3 (2008): 323-337.

Weiss, Michael J., 'Parallel universe', American Demographics 21 (1999): 58-63.

Wilson, G.A., 'The spatiality of multifunctional agriculture: a human geography perspective', Geoforum 40:2 (2009): 269-280.

Yamashita, Shinji, 'The Public Anthropology of Disaster: An Introductory Note' in Asian Anthropology 11:1 (2012): 21-25.

Zukin, Sharon, Landscapes of power: from Detroit to Disney World. Berkeley: University of California Press, 1991. 
Interview list

11 March, 2012, volunteer

10 May, 2012, social entrepreneur

29 July, 2012, social entrepreneur

29 July 2012, NGO employee

5 August 2012, NGO employee

13 August 2012, NGO employee

26 July 2014, local IT professional working in Tokyo

28 July 2014, Matsuzaki Ben

29 July 2014, local shop assistant

2 August 2014, Iida Akio

3 August 2014, Amano Yuki

4 August 2014, local restaurant owner

4 August 2014, former volunteer, social entrepreneur

4 August 2014, former volunteer, NGO employee 